\title{
Correlation between Social Support from Orphanage Administrator and Future Orientation of Teenager Living in Orphanage
}

\author{
Nissa Ramdhita Firghianti; Nuzul Mela Lestari; Nursia Sirait \\ Faculty of Education, Semarang State University, Indonesia
}

http://dx.doi.org/10.18415/ijmmu.v6i6.1208

\begin{abstract}
The objectives of the study are to determine the description of the future orientation of teenager living in orphanage, to know the description of social support from orphanage administrator, and to know whether or not there is a correlation between social support from orphanage administrator and the future orientation of teenager living in orphanage. This is a quantitative research. The subjects of the study were 200 teenagers living in orphanage. The sampling was carried out using total sampling technique. The data validity was done through validity and reliability tests. The data collection method was performed by using a psychological scale. The data analysis technique was performed using product moment correlation analysis. The results showed that the two research variables, social support from orphanage administrator and future orientation of teenager living in orphanage, are in the high category: $55 \%$ and $66 \%$. Based on the calculation results, the R-score between the variables of social support and future orientation is 0.526 with a significance of $0.000(\mathrm{p}<0.01)$. It means that there is a significant positive correlation between social support and future orientation of teenager living in orphanage.
\end{abstract}

Keywords: Future Orientation; Social Support; Teenager

\section{Introduction}

The orphanage is a very popular institution to shape the development of children who do not have a family or who do not live together with the family. The children of the orphanage are cared for by caregivers who take the place of parents in caring for, looking after and providing guidance so that later they become useful and responsible adults for themselves and the community (Sudarsana, 2018).

The results of the Ministry of Social, Save the Children, and UNICEF research in 2006 and 2007 of 37 orphanages in 6 provinces provide a comprehensive picture of the quality of care for orphanages in Indonesia as follows: Orphanages function more as institutions providing access to education rather than as institutions the last alternative for parenting a child who cannot be taken care by parents or family. $90 \%$ of children living in orphanages still have both parents and are sent to an orphanage with the main reason to continue their education. Since it is more dominant as a provider of access to education, children must stay long in the orphanage until graduating from high school and must undergo guidance from caregivers that they should receive from their parents. The orphanage administrator does not have 
adequate knowledge about the conditions and childcare ideally that should be given to children in the orphanage. Based on the results of interviews with several orphanage children, they live in an orphanage to continue their better education. Teenager who lives in the orphanage still has parents. In addition, their parents on average cannot afford to pay for school so they put their children in an orphanage.

Children who have lost their parents and orphans receive the same level of social support. In terms of sources of support, all orphans and vulnerable children are significantly more likely to attract support from friends and others than from family (Rahma, 2011). Research reveals that orphans in orphanages believe that they face problems related to care and support in the form of material or psychological (Mulia, 2014).

The orphanage environment becomes the main social environment for teenagers who live in the orphanage to make adjustments. The orphanage allows them to learn and gain first-time socializing experience with friends of the orphanage or caregiver. Teenager are demanded to develop and adapt as their main capital when they live in the wider community.

There are several orphanages that have sufficient attention. The orphanage administrator frees teenagers to determine their future. However, administrators cannot help them in determining the future. Thus, this is often confusing, especially when they graduate from school. When other teenagers want to continue school or work, some are still confused about their future. Moreover, in the end, there are some teenagers who do not try to change their future when they graduate from school and stay in an orphanage by helping orphanage administrators.

This has led to the future of teenagers in different orphanages. It starts not only from the state of a good or caring orphanage, but also from the attitude of the administrator who gives attention to teenagers, especially about their future. Not a few administrators of the orphanage wanted the teenager to succeed when they left the orphanage so they could change their former economic status. However, not a few administrators also do not pay attention to teenagers, especially regarding their future. Although orphanage administrators know that teenagers graduate from school, they do not really care whether the teenager wants to continue school or work.

The orphanage administrator gives different support to teenagers. It is caused by the different conditions of the orphanage where there is an orphanage in good condition and there is also an orphanage with an apprehensive condition so that administrators cannot provide support to teenagers. Thus, teenager orphanages have a different future orientation because they get different support.

\section{Research Method}

\section{Research Approach}

The research approach that the authors conduct includes quantitative research. Azwar (2012) states that a quantitative approach emphasizes the analysis of numerical data or numbers that are processed using statistical methods.

\section{Research Design}

The research design that researchers use is the correlation research design. Correlation research aims to investigate the extent to which variations in one variable are related to variations in one or more variables based on correlation (Azwar, 2012). 


\section{Research Variable}

Theoretically, variables can be defined as attributes of a person or object that has a "variation" between one person and another or one object with another object (Sugiyono, 2012). The variables that this study uses are as follows:

a. Dependent Variable : Future Orientation

b. Independent Variable : Social Support

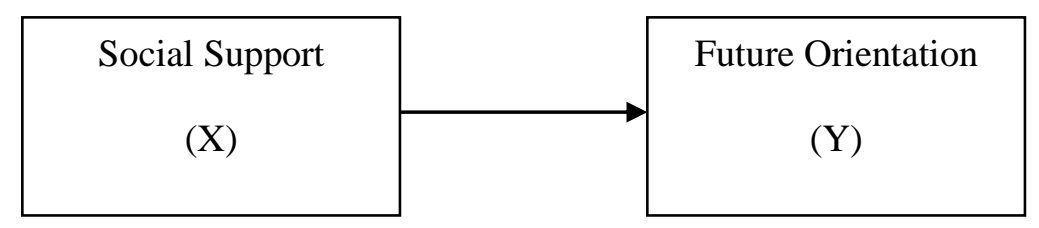

Figure 1. Correlation between Variables $X$ and $Y$

\section{Population and Sample}

The study population was teenagers living in orphanages. This study uses total sampling, which is one of the sampling techniques that is often used in research. Total sampling is a sampling technique where the number of samples is equal to the population (Sugiyono, 2012). The reason the authors chose the total sampling technique is that the number of samples that researchers need is limited. Thus, researchers used total sampling as a sampling technique. The selected districts include: South Bekasi, East Bekasi, Pondok Gede, Rawalumbu, Mustika Jaya, Jati Asih with a sample size of 200 children. Some subdistricts and orphanages were not selected because there were many invalid subjects.

\section{Data Collection Method}

Data collection method in research activities aim to uncover facts about variables under study (Azwar, 2012). Psychological scale contains questions or statements that indirectly reveal the attributes to be measured by revealing behavioral indicators of the attributes concerned. This study uses a Likert scale psychological model that contains statements about the research object (Azwar, 2012). This study uses two scales consisting of: the scale of future orientation taking and the scale of social support. The scale consists of two kinds of statements which include favorable statements (supporting or favoring objects) and unfavorable statements (not supporting objects).

\section{Data Analysis Method}

Hypothesis testing in this study employs bivariate correlation statistical method; i.e. statistics that researchers use to explain the correlation between two variables (Arikunto, 2006); in this case, future orientation and social support. From some existing techniques, this study was analyzed statistically through SPSS for Windows version 21.0. Data analysis method in this research is Product Moment analysis technique. The results will also be compared by providing appropriate criteria (Azwar, 2012) so that the following results are obtained: 
Table 1. Classification of Analysis Criteria Based on Hypothetical Mean

\begin{tabular}{|c|c|}
\hline Score Interval & Criteria \\
\hline$\mu+1 \sigma \leq X$ & High \\
\hline$\mu-1 \sigma \leq X<\mu+1 \sigma$ & Moderate \\
\hline$X<\mu-1 \sigma$ & Low \\
\hline
\end{tabular}

Description:

$\mu$ :Theoretical mean

๘:Standard deviation

\section{Research Result}

General Description of the Future Orientation of Teenagers Living in Orphanage

General description of the future orientation of teenagers living in orphanage in Bekasi City can be seen from the analysis of data with statistical calculations. Future orientation is measured using a scale of future orientation consisting of 18 valid items with the highest score of 5 and the lowest score of 1 .

Table 2. General Description of the Future Orientation of Teenagers Living in Orphanagein Bekasi City

\begin{tabular}{|c|c|c|c|}
\hline \multirow{2}{*}{ Score Interval } & \multirow{2}{*}{ Criteria } & F & Future Orientation \\
\cline { 3 - 4 } & & 131 & $65.5 \%$ \\
\hline $66 \leq \mathrm{X}$ & High & 69 & $34.5 \%$ \\
\hline $56 \leq \mathrm{X}<66$ & Moderate & 0 & $0 \%$ \\
\hline $\mathrm{X}<36$ & Low & 0 & \% \\
\hline
\end{tabular}

Based on the information in the table above, the future orientation of teenagers living in orphanages in Bekasi City is in the high category of $65.5 \%$ (131 people), is in the moderate category of $34.5 \%$ (69 people), and there is no in the low category. The description shows that the future of teenagers living in orphanages in Bekasi City is generally in the high category of $65.5 \%$.

Specific Description of the Future Orientation of Teenagers Living in Orphanage in Every Aspect

Future orientation can be seen from several aspects which include motivational aspect, planning aspect, and evaluation aspect. Description of each of these aspects can be explained as follows:

Table 3. Descriptive Summary of the Future Orientation of Teenagers Living in Orphanage

\begin{tabular}{|c|c|c|c|}
\hline \multirow{2}{*}{ Aspects } & \multicolumn{3}{|c|}{ Category } \\
\cline { 2 - 4 } & High & Moderate & Low \\
\hline Motivation & $56 \%$ & $41 \%$ & $3 \%$ \\
\hline Planning & $54.5 \%$ & $42.5 \%$ & $3 \%$ \\
\hline Evaluation & $70 \%$ & $28.5 \%$ & $1.5 \%$ \\
\hline
\end{tabular}


Based on the table and graph above, the majority of future orientations of teenagers living in orphanages in Bekasi City which are categorized based on their aspects are in the high category.

\section{General Description of Social Support of Teenagers Living in Orphanage in Bekasi City}

General description of the social support of teenagers living in orphanages in Bekasi City can be seen in the data analysis with statistical calculations. Social support is measured using a social support scale consisting of 25 valid items with the highest score of 5 and the lowest score of 1 .

Table 4. General Description of Social Support of Teenagers Living in Orphanage in Bekasi City

\begin{tabular}{|c|c|c|c|}
\hline \multirow{2}{*}{ Score Interval } & \multirow{2}{*}{ Criteria } & F & Social Support \\
\cline { 3 - 4 } & & 110 & $55 \%$ \\
\hline $91.6 \leq \mathrm{X}$ & High & 90 & $45 \%$ \\
\hline $58.4 \leq \mathrm{X}<91.6$ & Moderate & 0 & $0 \%$ \\
\hline $\mathrm{X}<58.4$ & Low & & 0 \\
\hline
\end{tabular}

Based on the information in the table above, social support for teenagers living in orphanages in Bekasi City is in the high category of 55\% (110 people), is in the moderate category by $45 \%$ (90 people), and none is in the low category. The description shows that the social support of teenagers living in orphanages in Bekasi City is generally in the high and moderate category.

\section{Specific Description of Social Support of Teenagers Living in Orphanage}

Social support can be seen from several aspects which include aspects of emotional support, aspects of appreciation support, aspects of instrumental support, and aspects of information support. An overview of each aspect of social support is explained as follows:

Table 5. Descriptive Summary of Social Support of Teenagers Living in Orphanage

\begin{tabular}{|c|c|c|c|}
\hline \multirow{2}{*}{ Aspects } & \multicolumn{3}{|c|}{ Category } \\
\cline { 2 - 4 } & High & Moderate & Low \\
\hline Emotional Support & $71 \%$ & $29 \%$ & $0 \%$ \\
\hline Appreciation Support & $57 \%$ & $42.5 \%$ & $0.5 \%$ \\
\hline Instrumental Support & $43 \%$ & $55.5 \%$ & $1.5 \%$ \\
\hline Information Support & $33.5 \%$ & $65 \%$ & $1.5 \%$ \\
\hline
\end{tabular}

Based on the table above, the social support of teenagers living in orphanage in Bekasi City has different categories for each aspect. In the aspect of emotional support and appreciation support, teenagers who live in orphanages in Bekasi City are generally included in the high category. Meanwhile, in the aspect of instrumental support and information support, the general description of teenagers living in orphanages in Bekasi City is included in the moderate category. 


\section{Normality Test}

To find out whether or not the distribution is normal, if $\mathrm{p}>0.05$ then the distribution is declared normal and if $\mathrm{p}<0.05$ then the distribution is abnormal. In the normality test on the scale of future orientation, the K-SZ coefficient is 1.607 with a significance value of 0.11 ( $p>0.05$ significant). These results indicate that the data distribution is normally distributed. Meanwhile, the normality test on the scale of social support obtained a K-SZ coefficient of 0.640 with a significance value of 0.807 ( $p>0.05$ significant). These results indicate that the data distribution is normally distributed. So, it is concluded that both scales have normal datadistribution.

\section{Linearity Test}

The calculation results obtained an F of 77.974 with $p=0.000$. Since $p<0.05$, the correlation pattern of social support and future orientation of teenagers living in orphanages in Bekasi City can be considered linear.

\section{Hypothesis Testing}

The correlation coefficient of social support and future orientation of teenagers living in orphanages in Bekasi City is 0.526 with a significance level of $p=0.000$ where $p<0.01$. This shows that the hypothesis stating that "there is a positive correlation between social support and future orientation of teenagers living in orphanage" is accepted. The value of the positive correlation coefficient shows a straight correlation where the correlation that occurs is a positive correlation. An increase in one variable will cause a decrease in another variable. It means that if the social support that teenagers get at an orphanage is positive, their future orientation will be positive.

\section{Discussion}

Discussion of Descriptive Analysis on Social Support from Administrator and the Future Orientation of Teenager

1. Descriptive Analysis of the Future Orientation of Teenagers Living in Orphanage in Bekasi City

Future orientation is a cognitive phenomenon where planning, which has the goal of being expected, will affect the individual towards the environment in the future. This future orientation has a very close relationship with hopes, goals, standards and plans and strategies undertaken to achieve a goal, dreams, and ideals. Future orientation describes how the individual sees him/herself in the futurecontext.

As a complex cognitive-motivational phenomenon, future orientation is closely related to cognitive schemes; i.e. a perceptual organization of past experience and its relation to present and future experience (Andrean \& Akmal, 2019). According to Steinberg (2009), the cognitive schemata interact with the three stages of the process of forming a future orientation which includes: a. motivation where the motivational stage is the initial stage of forming the future orientation of a teenager, b. planning which is the second stage of the process of forming an individual's future orientation, namely how teenagers make plans about the realization of their interests and goals, c. evaluation which is the last stage of the process of forming future orientation. Steinberg (2009) views evaluation as a process that involves observing and evaluating behavior that provides reinforcement for oneself. 
In general, the future orientation of teenagers living in orphanage in Bekasi City is in the high category with a percentage of $65.5 \%$ (131 people), is in the moderate category with a percentage of $34.5 \%$ (69 people), and is not in low category. These results indicate that most teenagers who live in orphanages in Bekasi City have a high future orientation, especially in the evaluation aspect of $70 \%$ which is in the high category.

These results are slightly different from the phenomenon that the researchers are studying. Based on preliminary studies, it is estimated that teenagers living in orphanages in Bekasi City have diverse future orientations because of the different orphanage conditions. The results of this study are similar to preliminary studies that have been conducted by helding interviews with teenagers and administrators of orphanages in BekasiCity. Teenagers who live in orphanages have a desire for a better future to change their educational status so that they get a better life and economic status.

Research conducted by Afifah (2009) on the economic status of the contents of the interests of teenagers shows that the future work life is more emphasized on lower class teenager thinking. Whereas middle class teenagers tend to be more interested in careers and educational recreational activities.

More detailed results regarding future orientation are illustrated in two aspects of future orientation. The aspect that shows the future orientation of teenagers living in orphanages in Bekasi City is the motivational aspect of $56 \%$ of respondents who state that they have high motivation towards future orientation.

The planning aspect gets a percentage of $54.5 \%$ which is in the high category. That shows that the teenager who lives in an orphanage in Bekasi City has careful planning.

Based on the above data, it is concluded that the evaluation aspect is the goal of the future orientation process which results in $70 \%$ of research respondents included in the high category.

This is slightly different from the phenomenon in the field where aspects of future orientation are in the high category, especially evaluation aspects. When teenagers have a future, they will have motivation and careful planning where they will evaluate it themselves even though the future of the plan has not been reached. Many research results conclude that goal directed behavior is more effective than behavior that is not directed by the goal. Someone who has clear goals will focus more on the things that drive him/her to achieve what he/she wants (Aarts \& Dijksterhuis, 2000).

\section{Descriptive Analysis of Social Support of Teenagers Living in Orphanage in Bekasi City}

This social support is an external source that will help individuals to overcome a problem and also describe the feelings or meaningful effects that can be caused by others; for instance, family members, friends, relatives, and coworkers. In general, teenager social support living in orphanage in Bekasi City is in the high category with a percentage of 55\% (110 people), is in the moderate category by $45 \%$ (90 people), and not in the low category. These results indicate that the social support of teenagers living in orphanages in Bekasi City is in the high and moderate category.

This is different from the phenomenon in the field where teenagers get social support from the environment around them, especially the administrator of the orphanage. Administrators of the orphanage still provide support to residents of the orphanage even though they are in large numbers. Not only administrators, residents of the orphanage also provide mutual social support to other residents. However, there are some orphanages where the environment especially the orphanage administrators cannot provide support to teenagers, especially in terms of making decisions about their future. 
Social support has also been recognized as having a significant impact on student achievement. Since family and friends are the individual's first source, support from these two sources was found to have a significant influence on academic achievement (Steinberg, 2009 and Cutrona et al, 1994). The support that the students receive can help to reduce their psychological problems because they feel that there is someone who helps them to perform well in academic life. By having knowledge about how social support can help students excel in dealing with any psychological disorders, a lot of information can be derived to increase the amount of this support.

The most behavior that shows that teenagers have social support is the aspect of emotional support and appreciation support. The results of the study found that $71 \%$ (142 people) of respondents stated that they received emotional social support and 29\% (58 people) of the other respondents were in the moderate category. The results of the award support are that 57\% (114 people) of respondents stated that they received award support, $42.5 \%$ (85 people) of respondents were in the moderate category, and $0.5 \%$ ( 1 person) of respondents were in the low category. It means that the orphanage teenager gets a lot of emotional social support and appreciation from the environment which is included in the high category.

This is a little different from the phenomenon on the ground where teenagers get emotional social support and appreciation from the environment around them, especially from orphanage administrators. Teenager feels comfortable with what is performed by those around them especially the orphanage administrator. For instance, the care of an orphanage gives attention and concern to a teenager. Teenagers in orphanages assume that the awards they get from orphanage administrators are very meaningful because teenagers feel they receive awards and support from orphanage administrators for their attitudes and behavior. Not a few orphanage administrators cannot provide support to teenagers, especially emotional support and appreciation because of constrained orphanage conditions that are densely populated. Thus, administrators cannot provide even support to orphans.

Kumalasari and Ahyani (2012) mention that social support is one function of social ties. These social ties illustrate the general level of quality of interpersonal relationships. Ties and friendships with others are considered aspects that provide emotional satisfaction in an individual's life. When someone is supported by the environment, everything will feel easier. Social support shows interpersonal relationships that protect individuals against the negative consequences of stress. Social support that individuals receive can make them feel calm, cared for, loved, confident, and competent. Reassurance of worth, social support is in the form of recognition or appreciation of the abilities and qualities of individuals (Cutrona et al, 1994). This support will make the individual feel himself accepted and valued. An example of this support is giving praise to individuals for doing something well.

Another behavior that shows that the social support that teenagers get in orphanages in Bekasi City is in the medium category is instrumental support and information support. In instrumental support, $55.5 \%$ (111 people) of respondents stated that they received moderate instrumental support, 43\% (86 people) respondents were in the high category, and 1.5\% (3 people) respondents were in the low category. Meanwhile, for information support, 65\% (130 people) of respondents were in the medium category, $33.5 \%$ (67 people) respondents were in the high category, and $1.5 \%$ (3 people) respondents were in the low category. These results indicate that the instrumental support and information support that respondents get is in the medium category.

Based on the phenomenon on the ground, social support for teenagers living in orphanages in Bekasi City is different. The environment provides good social support in terms of emotional and appreciation so that teenagers feel the support better. Meanwhile, in terms of instrumental and information support, teenager lacks social support. It can be caused by several factors existing in the environment; for instance, economics and environmental knowledge are lacking, especially from orphanage administrators. 
Reliable alliance is the knowledge possessed by an individual that he/she can rely on real help when it is needed. Individuals who receive this assistance will feel calm because he/she realizes there are people who can be relied upon to help him/her if he/she faces problems and difficulties (Cutrona et al, 1994). Guidance is social support in the form of advice and information from reliable sources. This support can also be in the form of providing feedback on something that an individual has done (Sarafino \& Smith, 2014).

Regarding orphans and abandoned children, researchers found that the perception of social support for orphans and abandoned children requires the support of family, friends, and orphanage administrators (Tricahyani \& Widiasavitri, 2016). Research reveals that orphans in orphanages believe that they face problems related to care and support in the form of material or psychological (Dewi \& Cahyani, 2015).

\section{Discussion on Inferential Analysis of Administrator Social Support and Future Orientation of Teenager}

The hypothesis in this study states that "there is a positive correlation between social support and future orientation of teenagers living in orphanages". Based on the analysis of data that has been carried out, this hypothesis is accepted with a correlation coefficient of 0.526 . This score means that social support provides an effective contribution of $27.60 \%$ towards future orientation. This condition indicates that the level of consistency of future orientation can be predicted by $27.60 \%$ by social support while the other $72.40 \%$ is determined by other factors not disclosed in this study; for instance, individual factors, namely a number of factors originating from within an individual which include self-concept, cognitive maturity and conceptual factors which include age, sex, socioeconomic status.

The significance value in this study is significant positive which means that there is a significant positive correlation between social support and future orientation. An increase in one variable will cause an increase in another variable and a decrease in one variable will cause a decrease in another variable. Based on these results, the higher the social support, the higher the future orientation of teenagers living in orphanages in Bekasi and vice versa.

This is in accordance with the results of Afifah's research (2009) which shows how social support and interaction that is fostered in the family will provide a very important influence for the formation of teenager orientation, especially in fostering an optimistic attitude in looking at their future. Teenager who gets love and support from parents will develop trust and a positive attitude towards the future, believe in the successes he/she has achieved, and be more motivated to achieve the goals that have been formulated in the future.

This is in line with Desmita's (2009) explanation stating that to direct goals, there are a number of factors that influence one's future orientation: individual factors which include developments throughout the anticipated life span, contextual knowledge, skills, self-concept, and attribution styles and environmental factors which includes family, peers, teachers, and the surrounding culture.

Teenagers who live in orphanages do not feel the full function of the family which cannot be replaced by peer groups or other social structures. The dormitory system at the orphanage is also considered not suitable for the growth/ development of children. The three functions are the family provides a "sense of cohesion" or emotional ties, the family provides a model of adaptability, and the family provides a network communication network.

Social support refers to experiences that are valued, respected, caring, and loved by others who are present in one's life (Gurung in Yasin, 2010). It may come from different sources such as family, 
friends, teachers, community, or affiliated social groups. Social support can come in the form of tangible assistance provided by others when needed which includes assessments of different situations, effective coping strategies, and emotional support. Several previous studies have shown that contact support is negatively correlated with psychological symptoms and disorders such as stress, depression and psychiatric disorders and positively correlated with physical and mental health (Allgöwer et al, 2001).

Research conducted by Afifah (2009) at Junior High School and\&Vocational High School of Pendidikan Dua Mei Foundation states that there is an influence between parental support on future orientation in the work area of teenagers. Based on the description above, the cause of a good future orientation for teenagers living in orphanages is due to the high social support received by teenager orphanages from the environment such as orphanage administrators, teachers, and friends. Desmita (2009) explains that teenagers need support from the environment because the environment is one of the factors that affect the future of individuals. The social support that teenagers receive from the environment in the form of encouragement, attention, appreciation, assistance and affection makes teenagers consider themselves loved, cared for, and valued by others. If the individual is received and valued positively, the individual tends to develop a positive attitude towards him/herself and more accepts and values him/herself.

The future orientation of the teenager who lives in an orphanage in Bekasi City is good (in the high category). Based on the aspects that make it up, it means that the teenager who lives in an orphanage in Bekasi City has a good evaluation in arranging the future. According to Kumalasari and Ahyani (2012), social support is an interpersonal relationship which contains the provision of assistance that involves aspects consisting of information, emotional attention, appreciation and instrumental assistance obtained by individuals through interaction with the environment. Each of these supports will have benefits for the recipient. So, it can help teenagers in overcoming their problems such as reducing stress, anxiety or various other stresses.

The social support that teenagers receive from the environment in the form of encouragement, attention, appreciation, help and affection makes a teenager consider him/herself loved, cared for, and valued by others. If the individual is received and valued positively, then the individual tends to develop a positive attitude towards him/herself and more accepts and respects him/herself. Thus, teenagers are able to live independently in the midst of the wider community in harmony (Kartika, D, 1986).

An analysis of research conducted by Wall, Covel, and Macintyre, entitled Implications of Social Support for Adolescents' Education and Career Aspirations, shows that for men and women, perceptions of opportunities predict educational aspirations and career expectations, whereas for women, colleagues, families, and teachers predict perceptions of opportunities, whereas for men family support is only a prediction of perceptions of opportunities. The results showed that women felt that teacher and peer support was better. Compared to men and their colleagues, women feel they have greater future opportunities, educational aspirations and career hopes and expectations. Both men and women show educational aspirations and hopes; Possible contributions from socio-economic conditions and gender socialization. The results of the study which state that social support is significantly positively correlated to future orientation can also be interpreted that social support can determine future orientation. Social support is one of the individual factors that makes a difference in the level of future orientation. Social support has an important role in determining future orientation. That is how individuals need support from the environment to determine the goals of the future. Someone who gets positive support from the environment can determine and decide a positive future for the individual him/herself and his/her environment.

It has the same results even though the subject of the study is different wherein in this study,gender is one of the distinguishing factors. Thus, the results have sufficient differences in social 
support received by male and female teenager. It is different from research which only prioritizes social support in aspects of emotional support, appreciation support, instrumental support, and information support.

Based on the results of this study, there are four aspects of social support that affect future orientation which include: emotional support, appreciation support, instrumental support, and information support (Sarafino \& Smith, 2014). Aspects that have contributed to the future orientation of teenagers living in orphanages are emotional support and information support. Both aspects have a high contribution compared to aspects of instrumental support and information support. In practice, all aspects can be used to provide support to teenagers living in orphanages in terms of determining their future orientation. However, many of the institutions that are unable to provide maximum support for teenagers are due to the lack of information and knowledge of administrators about the future desired by teenagers. In addition, financial factors sometimes become an obstacle for administrators to provide full support to teenager orphanages in determining their future in education and employment.

From the explanation above, social support is positively correlated with future orientation. It means that there is a correlation between social support and the future orientation of teenagers living in orphanage in Bekasi City.

\section{Research Limitation}

This study has the following limitations:

a. It requires a lot of time because they have to adjust schedules to collect respondents from each orphanage so that research does not interfere with their activities and arrange schedules so that the time of data collection in each orphanage does not clash with each other.

b. Almost all respondents have never filled in a psychological scale so researchers must explain in more detail and accompany them until the study is completed.

c. Almost all respondents chose answers that tended to feel socially appropriate.

\section{Conclusions}

Based on research that has been carried out, the following conclusions can be drawn:

1. The future orientation of teenagers living in orphanage in Bekasi City is in the high category. More future orientation is shown through evaluating the teenager's future goals that have been determined.

2. Social support for teenagers living in orphanages in Bekasi City is in the high category. The most indicated aspect is emotional support. 
3. There is a positive correlation between social support and the future orientation of teenagers living in orphanages in Bekasi City. Thus, the more positive social support for teenagers living in orphanages in Bekasi City, the higher the future orientation of teenagers living in orphanage in Bekasi City. Vice versa, increasingly negative social support for teenagers living in orphanages in Bekasi City will reduce the future orientation of teenagers living in orphanage in Bekasi City.

\section{References}

Aarts, H., \& Dijksterhuis, A. (2000). Habits as knowledge structures: Automaticity in goal-directed behavior. Journal of personality and social psychology, 78(1), 53.

Afifah. (2009). Pengaruh Dukungan Orang Tua Terhadap Orientasi Masa Depan Dalam Area Pekerjaan Pada Remaja. Skripsi. Jakarta : Universitas Islam Negeri Syarif Hidayatullah.

Allgöwer, A., Wardle, J., \& Steptoe, A. (2001). Depressive symptoms, social support, and personal health behaviors in young men and women. Health psychology, 20(3), 223.

Andrean, E., \& Akmal, S. Z. (2019). Bagaimana Remaja Panti Asuhan Memandang Masa Depan? Pentingnya Dukungan Lingkungan. Psycho Idea, 17(1), 52-66.

Arikunto, S. (2006). Prosedur penelitian suatu pendekatan. Jakarta: Rineka Cipta.

Azwar, S. (2012). Metode Penelitian. Yogyakarta: Pustaka Pelajar.

Cutrona, C. E., Cole, V., Colangelo, N., Assouline, S. G., \& Russell, D. W. (1994). Perceived parental social support and academic achievement: An attachment theory perspective. Journal of personality and social psychology, 66(2), 369.

Desmita. (2009). Psikologi Perkembangan. Bandung, PT Remaja Rosdakarya.

Dewi, G. K., \& Cahyani, B. H. (2015). Resiliensi Pada Remaja Yatim Piatu Yang Tinggal Di Panti Asuhan. Jurnal Spirits, 5(2), 29-36.

Kumalasari, F., \& Ahyani, L. N. (2012). Hubungan antara dukungan sosial dengan penyesuaian diri remaja di panti asuhan. Jurnal Psikologi: PITUTUR, 1(1), 19-28.

Mulia, L. O. (2014). Hubungan dukungan sosial teman sebaya terhadap tingkat resiliensi remaja di panti asuhan. Jurnal Online Mahasiswa Program Studi Ilmu Keperawatan Universitas Riau, 1(2), 1-9.

Rahma, A. N. (2011). Hubungan efikasi diri dan dukungan sosial dengan penyesuaian diri remaja di panti asuhan. Psikoislamika: Jurnal Psikologi dan Psikologi Islam, 8(2).

Sarafino, E. P., \& Smith, T. W. (2014). Health psychology: Biopsychosocial interactions. John Wiley \& Sons.

Steinberg, L. (2009). Science on Adolescent Development. 2009. 5:47-73. 
Sudarsana, I. K. (2018). Pemberdayaan Usaha Kesejahteraan Sosial Berbasis Pendidikan Agama Hindu Bagi Anak Panti Asuhan. JCES| FKIP UMMat, 1(1), 41-51.

Sugiyono. (2012). Metode Penelitian Pendidikan: Pendekatan Kuantitatif, Kualitatif dan R\&D. Bandung: Alfabeta.

Tricahyani, I. A. R., \& Widiasavitri, P. N. (2016). Hubungan antara dukungan sosial dengan penyesuaian diri pada remaja awal di panti asuhan Kota Denpasar. Jurnal Psikologi Udayana, 3(3), 542-550.

\section{Copyrights}

Copyright for this article is retained by the author(s), with first publication rights granted to the journal.

This is an open-access article distributed under the terms and conditions of the Creative Commons Attribution license (http://creativecommons.org/licenses/by/4.0/). 